\title{
触 New Disease Reports \\ First report of Tomato brown rugose fruit virus infecting sweet pepper in Italy
}

\author{
S. Panno ${ }^{1}$, A.G. Caruso ${ }^{1}$, G. Blanco ${ }^{2}$ and S. Davino ${ }^{1,3 *}$ \\ ${ }^{1}$ Department of Agricultural, Food and Forest Sciences, University of Palermo, Viale delle Scienze Ed. 5, 90128 Palermo, \\ Italy ; ${ }^{2}$ Bayer Crop Science Italia SRL, Milan, Italy ; ${ }^{3}$ Institute for Sustainable Plant Protection, National Research Council \\ (IPSP-CNR), Turin, Italy
}

*E-mail: salvatore.davino@unipa.it

Received: 13 Mar 2020. Published: 01 Apr 2020. Keywords: Capsicum annuum, outbreak, ToBRFV

In January 2020, about $85 \%$ of a red sweet pepper (Capsicum аппиит) crop in a greenhouse located in Ragusa province (Sicily, Italy) showed virus-like symptoms. Symptoms consisted of a slight mosaic and discoloration of young leaves, vein clearing on young leaves, browning of the stem with strong necrosis located in the intersection of the secondary branches, partial necrosis of the vegetative apex and marbling, mosaic and distortion of the fruits (Fig. 1). It is important to note that in 2019 the same greenhouse was cultivated with tomato, which had been removed due to extensive infection caused by Tomato brown rugose fruit virus (Panno et al., 2019a).

Thirty plants (15 diseased and 15 asymptomatic) were collected for subsequent analysis. In order to ascertain the causal agent of the disease, the samples were tested for the presence of Cucumber mosaic virus (CMV) and Tomato spotted wilt virus (TSWV) by RT-PCR (Panno et al., 2012), and for Tomato brown rugose fruit virus (ToBRFV) by immunocapture (IC) real time RT-PCR (Panno et al., 2019b). The results were negative for CMV and TSWV in all 30 samples while 18 samples (15 diseased and three asymptomatic) gave a positive signal in IC-real time RT-PCR. To confirm the presence of ToBRFV, RT-PCR with specific primers ToBRFV-F and ToBRFV-R (Alkowni et al., 2019) was done. Amplicons of the expected size, $560 \mathrm{bp}$, were obtained for the 15 diseased plants, while only one asymptomatic plant gave positive results. Four amplicons (three diseased and one asymptomatic plant) were purified using the UltraClean PCR Clean-Up kit (Mo-Bio, USA) and directly sequenced in both directions using an ABI PRISM 3100 DNA sequence analyser (Applied Biosystems, USA). The sequences obtained from the four samples had c. 99\% identity and one sequence was deposited in GenBank (GenBank Accession No. MT188668). BLAST analysis showed $99.6 \%$ identity with a Sicilian isolate of ToBRFV (ToB-SIC01/19; MN167466) (Panno et al., 2019b).

To examine symptom development in pepper, sap extracts of each of the four positive samples were mechanically inoculated into three sweet pepper plants. Plants were grown in sterilised soil in an insect-proof glasshouse, with a $14 \mathrm{hr}$ light photoperiod, and a target air temperature of $28 / 20^{\circ} \mathrm{C}$ day/night. Symptoms were recorded weekly. All inoculated plants developed the previously described symptoms, 45 days post inoculation. The systemic presence of ToBRFV was confirmed by RT-PCR.

Tomato and pepper crops represent about $70 \%$ of the market for fresh vegetable products in Sicily. Consequently, eradication measures are underway in this region, to try to contain the outbreak of ToBRFV. To our knowledge, this is the first report of Tomato brown rugose fruit virus on pepper in Italy and in Europe.

\section{References}

1. Alkowni R, Alabdallah O, Fadda Z, 2019. Molecular identification of tomato brown rugose fruit virus in tomato in Palestine. Journal of Plant Pathology 101, 719-723. http://dx.doi.org/10.1007/s42161-019-00240-7

2. Panno S, Caruso A G, Davino S, 2019a. First report of Tomato brown rugose fruit virus on tomato crops in Italy. Plant Disease 103, 1443. http://dx.doi.org/10.1094/PDIS-12-18-2254-PDN

3. Panno S, Davino S, Rubio L, Rangel E, Davino M, GarciaHernández J, Olmos A, 2012. Simultaneous detection of the seven main tomato-infecting RNA viruses by two multiplex reverse transcription polymerase chain reactions. Journal of Virological Methods 186, 152-156.

http://dx.doi.org/10.1016/j.jviromet.2012.08.003

4. Panno S, Ruiz-Ruiz S, Caruso AG, Alfaro-Fernandez A, Font San Ambrosio MI, Davino S, 2019b. Real time reverse transcription polymerase chain reaction development for rapid detection of Tomato brown rugose fruit virus and comparison with other techniques. PeerJ 7, e7928 http://dx.doi.org/10.7717/peerj.7928

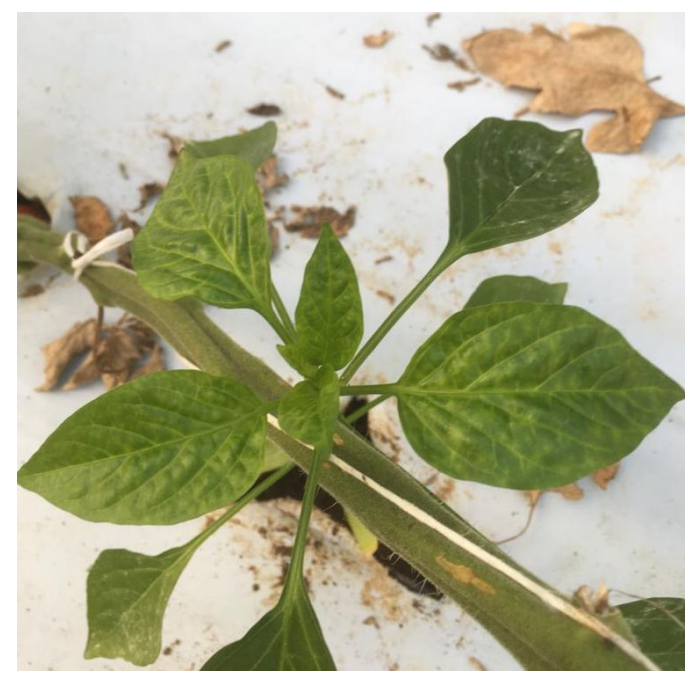

Figure 1

To cite this report: Panno S, Caruso AG, Blanco G, Davino S, 2020. First report of Tomato brown rugose fruit virus infecting sweet pepper in Italy. New Disease Reports 41, 20. http://dx.doi.org/10.5197/j.2044-0588.2020.041.020

(c) 2020 The Authors

This report was published on-line at www.ndrs.org.uk where high quality versions of the figures can be found. 